\title{
BED SEDIMENT DISTRIBUTION IN THE RIVER ESTUARY AND COASTAL SEA OF MALILI (SOUTH SULAWESI, INDONESIA)
}

\author{
Mahatma Lanuru ${ }^{1 *}$, Syafyudin Yusuf ${ }^{1}$ \\ Submitted: July 14, 2018, Accepted: August 10, 2018
}

\begin{abstract}
Bed sediment characteristics and distribution is one of the important parameters in determining the management plan and utilization of estuarine and coastal waters. The objective of this study was to analyze sediment distribution and determine dominant oceanographic factors controlling the distribution of bed sediment in the river estuary and coastal sea of Malili. Sediment samples were collected using a grab sampler at ten stations, namely four stations in the river estuary and six stations in the adjacent coastal sea for grain size and sediment organic content analysis. The results showed that the bed sediment along the river estuary consisted of silt, very fine sand, fine sand, and medium sand with organic content varying from 1.31 to 7.18 $\%$. In the coastal sea, bed sediment was dominated by silt with a higher organic content of $2.25-7.31 \%$
\end{abstract}

Keywords: bed sediment; sand; silt; organic content; river estuary; coastal sea; Malili

\section{INTRODUCTION}

The river mouth of Malili is one of the estuarine waters that play an important role in the lives of coastal communities in the East Luwu Regency (South Sulawesi). Aside from being a transportation channel that functions as a link between the river and the sea, the Malili estuarine water has long been used as a fishing ground by fishermen who live in the estuary and coastal area adjacent to the estuary.

The river mouth has a function as the discharge of river discharge into the sea (Triatmodjo, 1999). Also, the river mouth functions as a link between the river and the sea where there is a meeting between river currents and coastal currents. This current meeting will cause a sedimentation process at the river mouth (Satria et al., 2017; Poerbandono and Djunarsjah, 2005).

The problem that usually occurs in river mouth estuaries is the amount of sediment in the river mouth so that the cross-section becomes small and can disrupt the discharge of river water into the sea (Saratoga et al., 2015; Atmodjo, 2010). This problem is also found on the Malili River estuary where there is an increase in sediment in the river mouth so that it can hamper the fishing activities of fishermen and also the transportation activities of the ships from the sea to the river or vice versa through the Malili river mouth. Since there is a potential increase in sediment deposition at the river mouth of Malili estuary, it is important to study the distribution of the bed sediment and oceanographic factors controlling the distribution of bed sediment in the river mouth and coastal area of Malili is important to study the distribution of the bed sediment and oceanographic factors controlling the distribution of bed sediment in the river mouth and coastal area of Malili. In addition to understanding the sediment transport and

Corresponding Author:

Mahatma Lanuru ${ }^{1 *}$

Email: mahat70@gmail.com

${ }^{1}$ Departement of Marine Science, Hasanuddin University sedimentation processes, the study of bed sediment distribution is also important because sediment is a habitat for various kinds of aquatic biota that live at the bottom (benthos). Pollutants, especially heavy metals, are usually bound to sediment so that pollutant/ heavy metal transport is closely related to sediment transport in the waters. Information about the type and distribution of sediments at the bottom of the waters is also needed when conducting reclamation or dredging activities in an estuarine or coastal area (Anggraini et al., 2017).

The objective of this study was to analyze sediment distribution and determine dominant oceanographic factors controlling the distribution of bed sediment in the river mouth and coastal area of Malili.

\section{MATERIAL AND METHODS}

\section{Study Area}

This study was conducted in February 2018 at the river estuary and coastal sea of Malili. Ten-bed sediment samples were collected using a grab sampler for grain size and sediment organic content analysis. Four sediment samples were collected at the river estuary denoted as M1, M2, M3, and M4 and six samples (denoted as L1, L2, L3, L4, L5, and L6) were collected at the coastal sea (Figure 1).

\section{Sampling Method, Grain Size Analysis And Organic Content Analysis}

Bed sediment samples about 500 gr were collected at each station, stored in a plastic bag, and brought to the laboratory. In the laboratory, approximately 100 grams of sediment were dry sieved for 10 minutes using sieve net arranged in a sequence of mesh size $2 \mathrm{~mm}, 1 \mathrm{~mm}$, $0.5 \mathrm{~mm}, 0.25 \mathrm{~mm}, 0.125 \mathrm{~mm}$ and $0.063 \mathrm{~mm}$. The portion of sediment retained in each sieve is weighed and classified according to grain size using the Wentworth Scale. Gradistat-particle size analysis software was used to determine mean grain size (d50). 


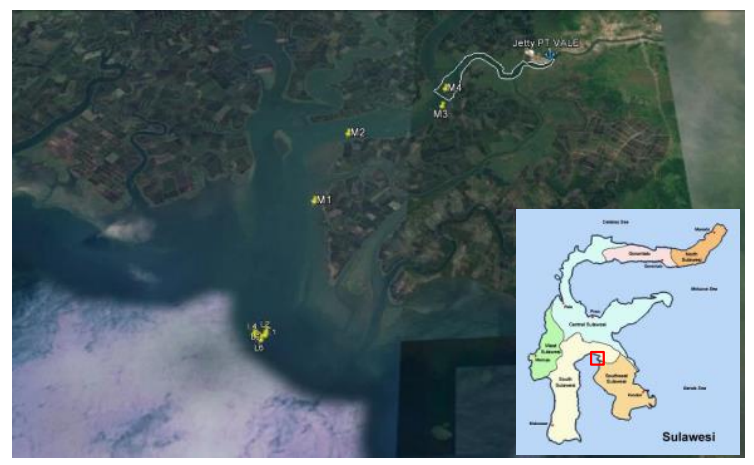

Figure 1. Study site and sampling stations in the river mouth (estuary) and a coastal sea of Malili

The sediment organic content was measured by loss of ignition of 1 - 2-gram dry sediment at $550{ }^{\circ} \mathrm{C}$ in an oven for $2 \mathrm{~h}$ following the method used by Fairhurst and Graham (2003). The following formula was used to calculate the sediment organic content (Lanuru 2004):

$$
\text { Organic content }(\%)=\frac{D W_{105}-D W_{550}}{D W_{105}} \times 100
$$

Where $D W 105=$ dry weight of the sample after oven drying at $105{ }^{\circ} \mathrm{C}$, and $D W 550=$ dry weight of the sample after combustion at $550^{\circ} \mathrm{C}$

\section{RESULT AND DISCUSSION}

The results of grain size analysis showed that the bed sediments at the river estuary of Malili varied from silt to medium sand (Table 1). Spatially, the bed sediment distribution at the river estuary shows that the sediment tends to be finer (smaller particle size) from the river upstream (Station M4) to the river downstream/river mouth (Station M1). Whereas in the coastal sea the size of the sediment particles was finer and relatively uniform which were dominated by silt.

Sediment grain size distribution in the river estuary and coastal sea of Malili are presented in Figure 2 and Figure 3, respectively. As shown in Figure 2, the particle size distribution in the river estuary was more diverse than in the coastal sea. As an example, the sediment at station M1 (river mouth) was dominated by particle less than $0.125 \mathrm{~mm}$ while at Station M4 (river upstream) the bed sediment was dominated by particle larger than $0.25 \mathrm{~mm}$.

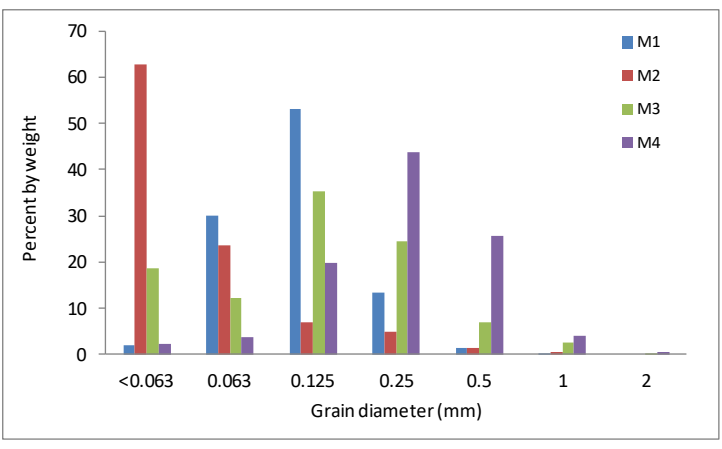

Figure 2. The grain size distribution of bed sediment in the river estuary

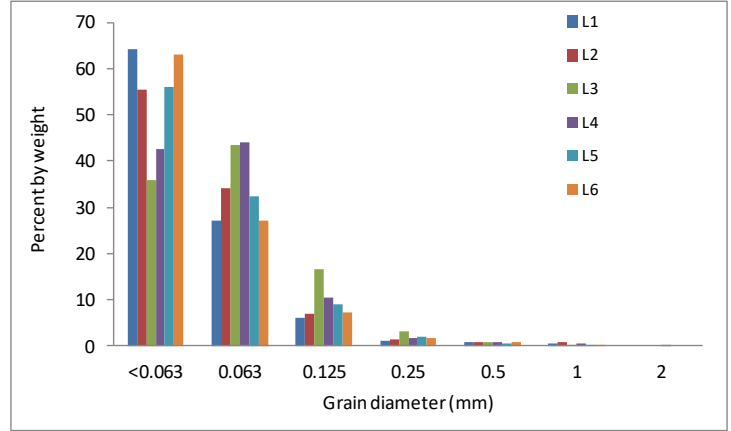

Figure 3. The grain size distribution of bed sediment in the coastal sea

In contrast to the river estuary, the particle size distribution of sediment in the coastal sea does not show a large difference among stations or in other words the particle size distribution is relatively uniform (Figure 3). The difference in sediment grain size distribution between river estuary and coastal sea can also be seen clearly in Figure 2 and Figure 3 where the size of sediment particles in the coastal sea was dominated by the particle size of less than $0.063 \mathrm{~mm}$.

The spatial distribution pattern of bed sediment at the study site show that particle sizes were getting smaller or finer from the land to the coastal sea. Sediments with a larger size or coarser grain tend to settle first in the river estuary or near the land due to their gravity whereas small fine sediments tend to be transported further by the current because of its small gravity and tend to be suspended in the water column so that it can be transported further to the sea and settles in deeper waters.

In addition to the sediment gravity, the difference in the size of sediment particles in the river estuary and coastal sea at the study site was strongly influenced by differences in hydrodynamic conditions, especially current velocity. The results of current pattern modeling using SMS (Surface Water Modeling System) 8.0 software show that the current velocity at the Malili river estuary varies from 0.14 to $1.40 \mathrm{~m} / \mathrm{s}$ (Figure 4) while in the coastal sea current velocity is much smaller, i.e. less than $0.12 \mathrm{~m} / \mathrm{s}$ (Figure 5). Coastal sea waters with relatively low current speeds allow fine sediments, especially silt, to settle in the sea. On the other hand, in the river estuary the current velocity is more varied from small to large (can reach up to 1.40 $\mathrm{m} / \mathrm{s}$ ) so that the sediment deposited in the river estuary also varies as observed in this study.

Sediment organic content at the study site varied from 1.31 to $7.18 \%$ at the river estuary. Whereas in the coastal sea, sediment organic content was greater, which varies from $2.25-7.31 \%$. Small, fine-sized sediments usually contain more organic matter than large coarse sediments. In this study, we observed a strong correlation between the particle size of sediment and the organic content of sediments, where finer sediments tend to have greater organic content (Figure 6). 


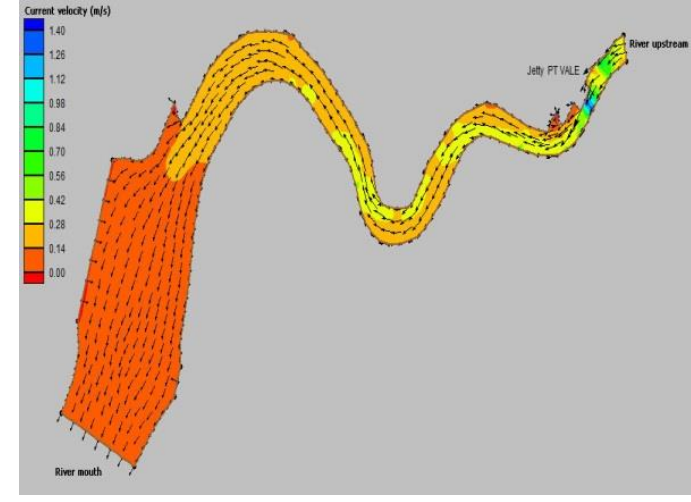

Figure 4. Hydrodynamic model of tidal current velocity and direction during low tide at the river estuary of Malili (Lanuru et al., 2016)

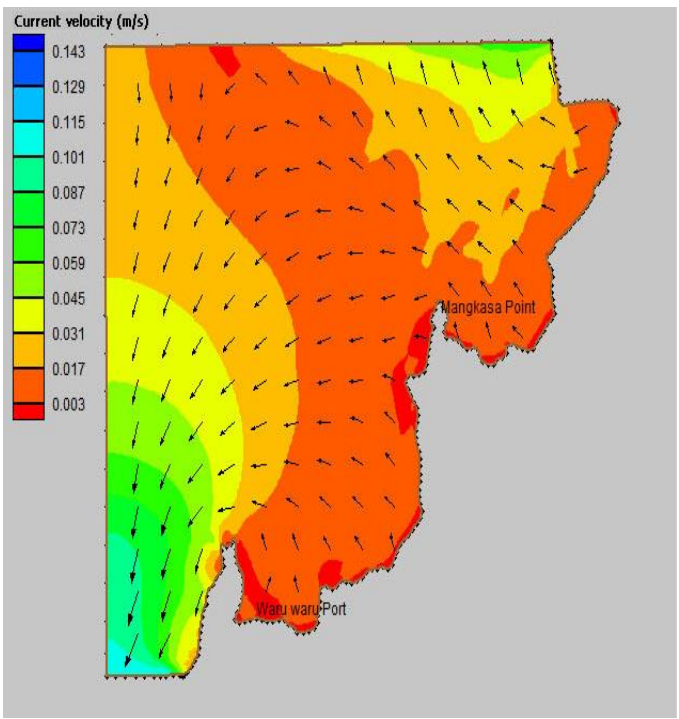

Figure 5. Hydrodynamic model of tidal current velocity and direction during low tide at the coastal sea of Malili (Lanuru et al., 2015).

The same phenomenon was also found by Hakim et al. (2015) in the Pulau Tikus water, Bengkulu (Indonesia) and Arisa et al. (2014) in the coastal water of Slamaran Pekalongan (Indonesia).

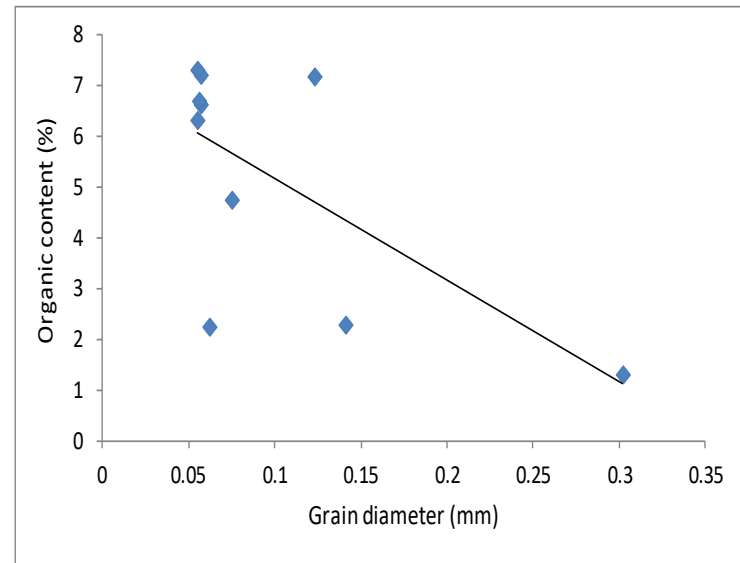

Figure 6. The relationship between bed sediment grain size and organic content.
Table 1. Sediment particle size, type of sediment, and sediment organic content $(\mathrm{M}=$ river estuary, $\mathrm{L}=$ coastal sea).

\begin{tabular}{llll}
\hline Sampling & $\begin{array}{l}\text { Mean } \\
\text { grain } \\
\text { size } \\
(\mathrm{mm})\end{array}$ & Sediment & Sediment \\
station & $\begin{array}{l}\text { organiccontent } \\
(\%)\end{array}$ \\
\hline M1 & 0.123 & $\begin{array}{l}\text { Very fine } \\
\text { sand }\end{array}$ & 7.18 \\
M2 & 0.056 & Silt & 6.7 \\
M3 & 0.141 & Fine sand & 2.29 \\
M4 & 0.302 & $\begin{array}{l}\text { Medium } \\
\text { sand }\end{array}$ & 1.31 \\
L1 & 0.055 & Silt & 6.32 \\
L2 & 0.057 & Silt & 6.63 \\
L3 & 0.075 & Very fine & 4.75 \\
L4 & 0.062 & Silt & 2.25 \\
L5 & 0.057 & Silt & 7.21 \\
L6 & 0.055 & Silt & 7.31 \\
\hline
\end{tabular}

\section{CONCLUSION}

Bed sediment at the Malili river estuary varied from silt to medium sand. Whereas in the coastal sea, bed sediment was dominated by silt. Spatial analysis of grain size distribution showed that grain size was getting smaller or finer from river estuary to coastal sea at the study site. Sediment grain size and hydrodynamic conditions (current velocity) of waters are the main factors that determine the pattern of bed sediment distribution at the study site.

\section{ACKNOWLEDGMENTS}

Thank you to PT Vale Indonesia for funding this research and Hasanuddin University for providing research facilities. Thanks also to anonymous students of Marine Sciences Department (Hasanuddin University) who have helped in sediment sampling and to Ibrahim, S.Kel who has helped create a hydrodynamic (current speed and direction) model at the study site.

\section{REFERENCES}

Anggraini, T. Z. A., M. I. Jumarang and Apriansyah. 2017. Studi Material Sedimen Perairan Pesisir Pantai Sungai Duri Kabupaten Bengkayang. Prisma Fisika V (1): 41 - 44 .

Arisa, R.R.P., E.W. Kushartono and A. Atmodjo. 2014. Sebaran sedimen dan kandungan bahan organik pada sedimen dasar perairan Pantai Slamaran Pekalongan. Journal of Marine Research 3 (3): 342 - 350.

Atmodjo, W. 2010. Sebaran Sedimen di Perairan Delta Sungai Bodri, Kendal, Jawa Tengah. Ilmu Kelautan 15 (1): 53 - 58. 
Fairhurst, R.A., and K.A. Graham. 2003. Seagrass bedsediment characteristics of Manly Lagoon. In: Freshwater Ecology Report 2003. Department of Environmental Sciences, University of Technology, Sydney.

Hakim, A.R., Mursalim and M. Makmur. 2015. Hubungan ukuran butir sedimen dengan kandungan total organik carbon pada sedimen Perairan Pulau Tikus, Bengkulu. Jurnal Oseanografi 4 (3): 585 - 589.

Lanuru, M., 2004. The spatial and temporal patterns of erodibility of an intertidal flat in

The East Frisian Wadden Sea, Germany. GKSS Report 2004/14, 138 pp.

Lanuru, M., S. Yusuf., Sahabuddin and B. Syafiuddin. 2016. Baseline study dan analisa kegiatan pra pengerukan di muara sungai Malili. Laporan Akhir. Universitas Hasanuddin. 101 hlm.

Lanuru, M., S. Yusuf, M. Lukman and B. Syafiuddin. 2015. Kajian tumpahan minyak perairan Mangkasa Point. Laporan Akhir. Universitas Hasanuddin. $129 \mathrm{hlm}$.

Poerbandono and E, Djunarsjah. 2005. Survei Hidrografi. Refika Aditama: Bandung. $116 \mathrm{hlm}$

Saratoga, E.E., S. Saputro and S. Widada. 2015. Sebaran sedimen dasar di perairan muara sungai Bagong, Teluk Lembar. Jurnal Oseanografi 4 (1): $116-123$.

Satria, F.W., S. Saputro, S and J. Marwoto. 2017. Analisa pola sebaran sedimen dasar muara sungai batang Arau Padang. Jurnal Oseanografi 6 (1): 47 - 53

Triatmodjo, B. 1999. Teknik Pantai. Beta Offset, Yogyakarta. 